\title{
ASSESSMENT OF LAND USE CHANGE IN SHIVAPURI NAGARJUN NATIONAL PARK: THE CASE OF SUNDARIJAL VDC, KATHMANDU
}

\author{
Sujata Shrestha*1, Laxman Joshi ${ }^{2}$ and Mukesh Dangol ${ }^{3}$ \\ ${ }^{1}$ Visiting Faculty, Kathmandu University School of Arts, Hattiban, Lalitpur, Nepal \\ ${ }^{2}$ Freelancer, Harishiddi, Lalitpur \\ ${ }^{3}$ Independent Researcher, Sunakothi, Lalitpur \\ *Email: shrestha_suj@hotmail.com
}

\begin{abstract}
This research aimed to assess land use and its change between 1990, 2000 and 2010 in Sundarijal VDC of Shivapuri Nagarjun National Park (SNNP). Land use change was assessed using Landsat TM data for 1990, 2000 and 2010. The drivers of land use change and its implications on ecosystem services were studied through field study comprising reconnaissance survey, questionnaire survey, key informant interviews and focus group discussions. GIS analysis showed that forest land and bare land area declined by $0.19 \%$ and $0.53 \%$, respectively from 1990 to 2010, while agricultural land increased by $0.72 \%$. The local people see the change in water quantity and quality, soil erosion and biodiversity loss as impacts of land use change. The key drivers of land use change include over harvesting of fuel wood for alcohol production, timber extraction and non-conducive government policies. Due to limited livelihood options, people residing inside SNNP boundary are involved in illegal extraction of fuel wood mainly for alcohol production. Respondents stressed that alternative livelihood options are required for minimizing such illegal activities.
\end{abstract}

Key words: Land use change, Livelihood, Sundarijal, Ecosystem services.

\section{INTRODUCTION}

The term 'land use' describes any activity, arrangement or use that occurs directly on the land or immediate actions modifying or converting land cover. It includes broad categories of human settlements, protected area, agricultural area, industrial zone, residential zone, etc. Land use is the key for providing food, fiber, shelter and environmental services essential for human sustenance and well-being (DeFries et al. 2007). There is an established direct link between land use and land cover, and action of people in environment may lead to the land cover change (Phong 2004).

Protected Areas (PAs) are considered an effective approach for conserving biodiversity and natural ecosystems. Many developing countries like Bhutan, Nepal, Thailand, Chile, Zimbabwe and Togo have declared more than 10 percent of their land as protected area (Ghimire 1994). However, conservation inside the PAs is affected by human and/or natural alteration of land use leading to changes in regional and global environmental system (Vitousek et al. 1997). In 
fact, humans are recognized as a dominant force in land use change (CISEIN 2002, Lamichhane 2008) with considerable negative impact on soils, water quality, microclimate, methane and carbon emission (Awasthi 2004, Lamichhane 2008). This also increases the vulnerability of land and people to climatic, economic and socio-political stresses. Concerns about the impact of land use change in protected areas at local, regional and global levels have been raised (CISEN 2002).

Located in the North-East of Kathmandu valley, Sundarijal watershed in SNNP is a strategically important protected area. SNNP is a story of quint essential conservation at the cost of local livelihoods. There are people living inside the park and they have literally been fenced in, and are subjected to "command and control". This conservation approach has improved the land use and ecosystem of the catchment significantly. On the contrary, the local peoples' status remains very poor. Many households live in poverty especially through wildlife-people conflict. Without alternative livelihood means, most local people are engaged in illegal firewood harvesting, used for producing (illegal) local alcohol for markets in Kathmandu. This has enhanced the deforestation and land degradation inside the park seriously affecting its ecosystem services.

SNNP is a major source of water for the inhabitants of Kathmandu valley. Apart, the water that flows from the watershed is collected and channeled to a power house located at Sundarijal which has a capacity of $4.77 \mathrm{GHz}$. In addition, the water is used by the mineral water companies and farmers downstream. However, the water is collected and used for free and there has not been any mechanism to incentivize the park management and the upstream local communities who play a significant role in resource management. Also, the water quantity and quality supplied to the downstream has been dwindling due to lack of conservation efforts in the upstream.
Thereby, there are challenges to maintain human land use option including preserving crucial habitats and reducing dependence of local human population on protected area resources. Hence, this study aimed to 1) assess land use and its change between 1990, 2000 and 2010 in Sundarijal VDC of SNNP, 2) find out local perceptions on land use change and its impacts on key ecosystem services, and 3 ) to determine the drivers of land use change.

\section{MATERIALS AND METHODS}

\section{Study area}

The study was conducted in the Sundarijal VDC inside SNNP. The focus of assessment is Sundarijal catchment within SNNP which is a major source of drinking water for the inhabitants of Kathmandu Valley. Sundarijal catchment is the origin of the city's largest river Bagmati and its two rivulets Nagmati and Shyalmati. Within the national park and inside Sundarijal catchment, there are three villages; Mulkharkha, Chilaune gaun and Okhreni with 323 households (Sundarijal VDC 2008/09).

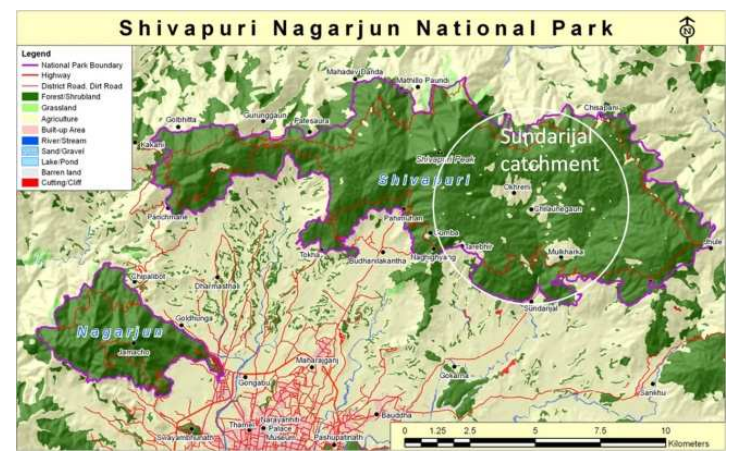

Fig. 1. Maps showing study area SNNP.

\section{Research design}

The research process included literature review, background check, expert consultations and reconnaissance visit to the study site that helped in formulating and sharpening research questions and setting research objectives. This was followed by desk study and collection of secondary GIS data. Land use change was assessed using

ECOPRINT VOL 20, 2013 
Landsat TM data for 1990, 2000 and 2010. A household survey was carried out using tailor made and pre-tested questionnaire in all three villages. The survey also included drivers of land-use change and local people's perception on the impact of land-use change on ecosystem services. The collected data were analyzed through the Index of Relative Ranking (IRR) (Miller 1986).

$$
\operatorname{IRR}=\frac{\mathrm{R}_{1} \mathrm{~S}_{1}+\mathrm{R}_{2} \mathrm{~S}_{2}+\ldots+\mathrm{R}_{\mathrm{n}} \mathrm{S}_{\mathrm{n}}}{\mathrm{n} \mathrm{r}}
$$

Where, IRR = Index of Relative Ranking

$\mathrm{R}_{1}=$ Rank of first order (No. of observation on first order)

$S_{1}=$ Score of highest rank (6)

$R_{n}=$ Rank of last order (No. of observation on last order)
$\mathrm{S}_{\mathrm{n}}=$ Score of lowest rank (1)

$\mathrm{n}=$ Number of observation

$r=$ Total rank given to particular attribute

Field study included reconnaissance survey, focus group discussions (FGD), field observations, informal interviews, household survey and key informant interview (KII). The detail process of research design is illustrated in Fig. 2.

\section{RESULTS AND DISCUSSION}

\section{Land use}

The classified Landsat TM was converted to vector ESRI shape file by the application of Arc GIS 9.3 software which gave the land use and land cover map of the study area for 1990, 2000 and 2010 as shown in Fig. 3.

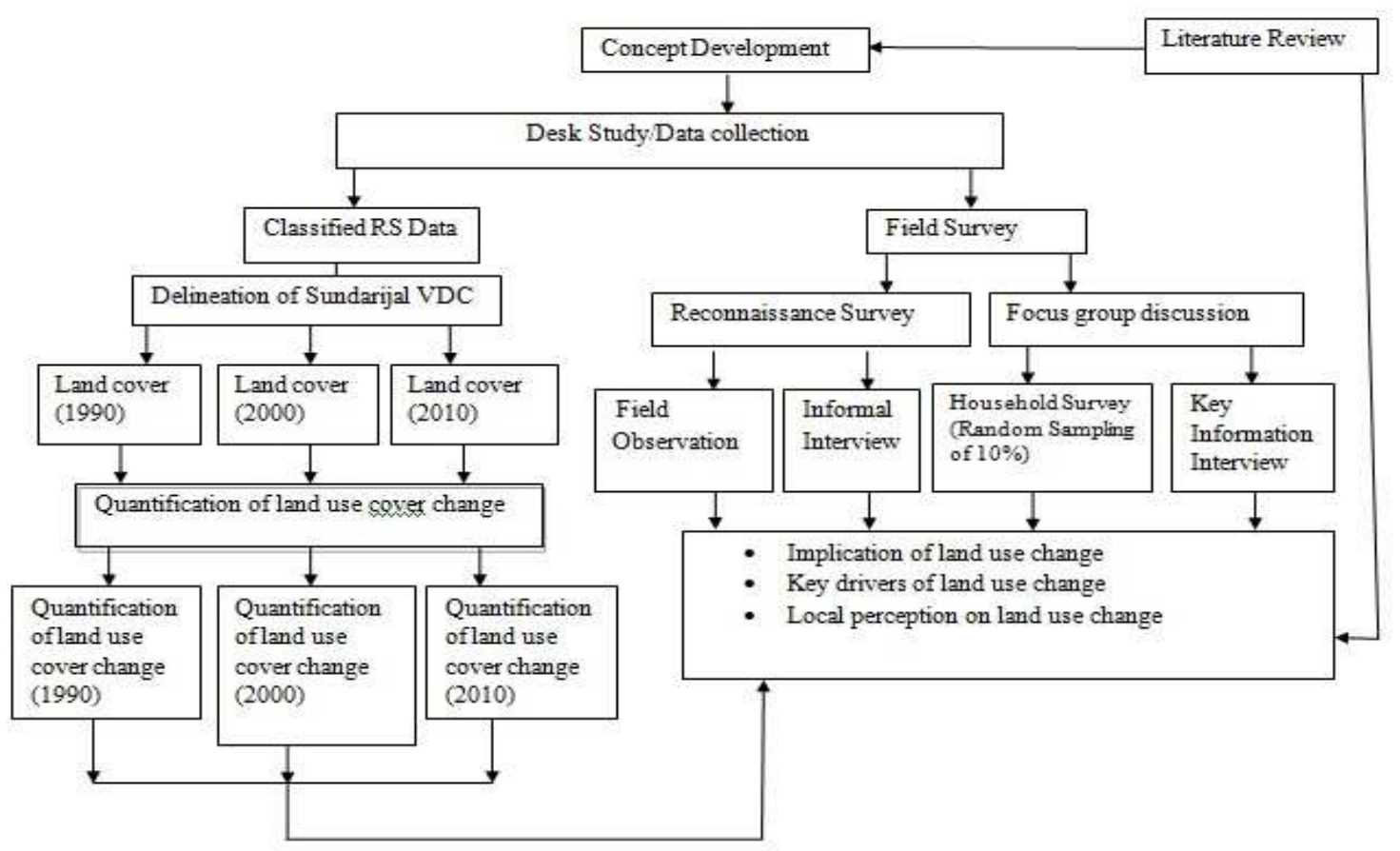

Fig. 2. Outline of the Research design used in the study. 


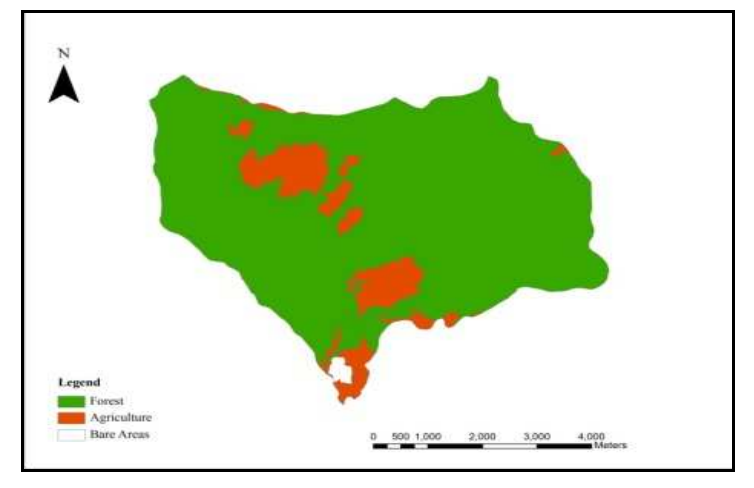

1990

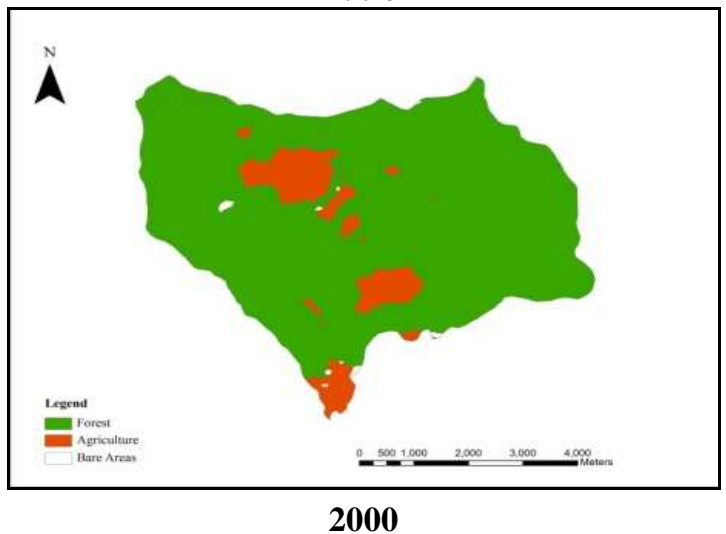

2000

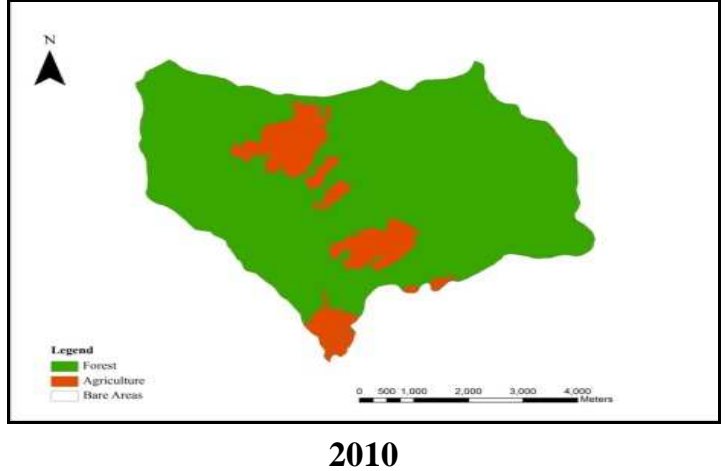

Fig. 3. Land use and land cover map of Sundarijal VDC of 1990, 2000 and 2010.

Assessment of land use and land cover classification was based on Landsat TM data of 1990, 2000 and 2010 for Sundarijal catchment. The images were classified into three classes forest land, agriculture land and bare land only due to the limited resolution of Landsat TM. The study area occupies 3525 ha. Out of this, GIS data showed that in 1990 forest was the predominant 56 major land use system covering 3110.9 ha $(88.3 \%)$ of the total VDC. This was followed by agricultural land with 395.1 ha $(11.2 \%)$ and bare land 18.8 ha $(0.53 \%)$. In 2000 , even though forest cover had increased to 3176.9 ha $(90.1 \%)$, agricultural land and bare land had decreased to 334.8 ha $(9.5 \%)$ and 13 ha $(0.4 \%)$, respectively. In 2010, the forest area had decreased to 3104.2 ha $(88.1 \%)$. In a time span of 10 years, agricultural land had increased by 420.6 ha $(11.9 \%)$ and bare land had totally disappeared (Table 1).

Table 1. Land use and land cover in 1990, 2000 and 2010.

\begin{tabular}{lccccccc}
\hline Class & \multicolumn{2}{c}{1990} & \multicolumn{2}{c}{$\mathbf{2 0 0 0}$} & \multicolumn{2}{c}{$\mathbf{2 0 1 0}$} \\
& Area (ha) & $\%$ & Area (ha) & \% & Area (ha) & \% \\
\hline Forest & 3110.88 & 88.26 & 3176.89 & 90.13 & 3104.17 & 88.07 \\
$\begin{array}{l}\text { Agricultural } \\
\quad \text { land }\end{array}$ & 395.07 & 11.21 & 334.83 & 9.50 & 420.57 & 11.93 \\
Bare land & 18.80 & 0.53 & 13.01 & 0.37 & 0 & 0 \\
Total & 3524.74 & 100 & 3524.74 & 100 & 3524.74 & 100 \\
\hline
\end{tabular}

\section{Land use change}

Between 1990 and 2000 forest land increased by 66 ha $(1.87 \%)$ at the expense of agricultural land and bare land coverage - 60.2 ha $(1.71 \%)$ and 5.8 ha $(0.16 \%)$, respectively. However, a reverse trend, i.e. decrease in forest land by 72.7 ha $(2.06 \%)$ and increase in agricultural land by 85.7 ha $(2.43 \%)$ were observed from 2000 to 2010 . Data for change in forest cover, agricultural and bare land from 1990 to 2000,2000 to 2010 and 1990 to 2010 are shown in Table 2.

Table 2. Land use change from 1990 to 2010.

\begin{tabular}{|c|c|c|c|c|c|c|}
\hline \multirow[t]{2}{*}{ Class } & \multicolumn{2}{|c|}{ 1990-2000 } & \multicolumn{2}{|c|}{$2000-2010$} & \multicolumn{2}{|c|}{ 1990-2010 } \\
\hline & $\begin{array}{c}\text { Change } \\
\text { (ha) }\end{array}$ & $\%$ & $\begin{array}{c}\text { Change } \\
\text { (ha) }\end{array}$ & $\%$ & $\begin{array}{c}\text { Change } \\
\text { (ha) }\end{array}$ & $\%$ \\
\hline Forest & 66.0 & 1.87 & -72.72 & -2.06 & -6.71 & -0.19 \\
\hline $\begin{array}{l}\text { Agricultural } \\
\text { land }\end{array}$ & -60.2 & -1.71 & 85.74 & 2.43 & 25.5 & 0.72 \\
\hline Bare land & -5.8 & -0.16 & -13.01 & -0.37 & -18.8 & -0.53 \\
\hline
\end{tabular}

On an annual basis, forest area increased at about $0.18 \%$ per year between 1990 and 2000; while agricultural land decreased at $0.17 \%$ per 
annum. Bare land likewise decreased by $0.02 \%$ per year. Between 2000 and 2010 deforestation rate increased to $0.21 \%$ per year and agricultural land expanded at a rate of $0.24 \%$. Overall forest land conversion between 1990 and 2010 was found to be $0.02 \%$ per annum and agricultural land expanded by $0.07 \%$ per annum (Table 3 ).

Table 3. Annual land use change from 1990 to 2010.

\begin{tabular}{lccc}
\hline \multicolumn{4}{c}{ Annual Change (\%) } \\
Class & $\mathbf{1 9 9 0 - 2 0 0 0}$ & $\mathbf{2 0 0 0 - 2 0 1 0}$ & $\mathbf{1 9 9 0 - 2 0 1 0}$ \\
\hline Forest & 0.18 & -0.21 & -0.02 \\
Agricultural & -0.17 & 0.24 & 0.07 \\
$\quad$ land & & & \\
Bare land & -0.02 & -0.04 & -0.05 \\
\hline
\end{tabular}

\section{Key drivers of land use change}

Analysis of survey data for drivers of land use change indicated that firewood harvesting, timber harvesting, economic activities of alcohol production, population growth and counterproductive governmental policies are important (Table 4).

Table 4. Key drivers of land use change.

\begin{tabular}{lccc}
\hline Drivers of land use change & $\begin{array}{c}\text { Sum of } \\
\text { Score }\end{array}$ & \multicolumn{2}{c}{ IRR Rank } \\
\hline Firewood over harvesting & 138 & 6.3 & 1 \\
Timber over harvesting & 124 & 5.7 & 2 \\
$\begin{array}{l}\text { Economic activities (alcohol } \\
\quad \text { production) }\end{array}$ & 107 & 4.7 & 3 \\
$\begin{array}{l}\text { Population increase in the } \\
\quad \text { villages }\end{array}$ & 84 & 3.9 & 4 \\
$\begin{array}{l}\text { Government Policy } \\
\text { Hotels and tourists }\end{array}$ & 81 & 3.7 & 5 \\
Infrastructure development & 41 & 1.9 & 6 \\
\hline
\end{tabular}

\section{Impact of deforestation on ecosystem services}

The local respondents perceived that conversion of forest land into agricultural land leads to negative impacts on ecosystem services. The adverse consequences of forest deterioration include (in order of priority) included reduction in water quantity, quality, increase of soil erosion, reduction in biodiversity, landscape beauty and religious or touristic value (Table 5).

Table 5. Ecosystem services affected by forest destruction.

\begin{tabular}{lccc}
\hline Impact on Ecosystem services & $\begin{array}{c}\text { Sum of } \\
\text { Score }\end{array}$ & IRR & Rank \\
\hline Reduced water quantity & 104 & 4.72 & 1 \\
Reduced water quality & 94 & 4.27 & 2 \\
Soil erosion & 88 & 4 & 3 \\
Biodiversity loss & 68 & 3.09 & 4 \\
Reduced landscape beauty & 65 & 2.95 & 5 \\
$\begin{array}{l}\text { Reduced religious/touristic } \\
\quad \text { value }\end{array}$ & 35 & 1.6 & 6 \\
\hline
\end{tabular}

This study showed that there was gradual improvement in forest land before 2000 but after 2000 forest land declined significantly $(0.21 \%$ per annum). Overall deforestation rate in 20 years (1990-2010) was $0.02 \%$ per annum which is quantified to be higher than forest land degradation in PAs in the Terai region $(0.01 \%)$ between 1991 to 2001 (DoF 2005). The local people's perception of the decreasing forest cover and increasing agricultural land is in line with results of GIS data analysis. Firewood extraction for alcohol production was reported to be in increasing trend which has led to the decreasing number of trees near settlements. This has significantly increased the distance and time required for locals to the forest resource. Deforestation and forest degradation inside SNNP is real and likely to increase in future as the villages inside the park are now accessible with a motorable road to the Kathmandu valley.

Local people are also aware of adverse effects of forest destruction on ecosystem goods and services such as decline in water availability and quality, soil loss and biodiversity loss. A study of Panta and Rasul (2008) reported a positive relationship between watershed conservation upstream and water yield downstream. The study revealed an increasing shortage of drinking water 
in the Kathmandu as water demand has increased considerably over the past few decades. The supply has been dwindling due to poor management and degradation of adjacent watershed of SNNP. The demand for water in Kathmandu is about 270 million litres daily but KUKL is supplying only 100 million litres per day. Water shortage is affecting the lives of 1.5 million people in Kathmandu with adverse impact on their health and environment. Moreover, degradation of watershed has affected the quality of water in Kathmandu causing increased waterborne diseases and affecting public health (Pant and Rasul 2008). A similar study conducted by Bhattarai et al. (2008) on water quality of Sundarijal reservoir and its feeding streams in Kathmandu claimed that physico-chemical characters are within the standard of World Health Organization (WHO) and European Commission (EU) for stream water. However, the coliform bacteria were found high and water is unsafe for consumption without intense treatment and disinfection. Most respondents do not use toilet but go down to the river for defecation. There is lack of awareness on sanitation and hygiene - a major reason for high Coliform bacteria in river water. The local farmers use fertilizers and pesticides on agricultural crops; these agrochemicals later leach into river water. Similarly, haphazard road construction inside the three villages also poses serious problem of soil erosion, landslides and siltation in reservoir downstream.

In case of SNNP, the study showed that major drivers of land use change included firewood harvesting, timber harvesting, alcohol production and inadequate government policy. Majority of respondents depend on firewood for their energy needs. Limited livelihood opportunities force the villagers to engage in illegal alcohol production that requires much energy. Likewise, local population increase and tourism in the villages are also putting high pressure on forest resources. The local people also see national policies, rules and regulations for conservation as conflicts with their necessity for firewood and timber.

\section{CONCLUSION}

In the study area, forest land decreased by $0.19 \%$ (about 3104 ha) or $0.02 \%$ per year over the 20 year period between 1990 and 2010; this was mainly converted to agricultural land. Agricultural land increased by $0.72 \%$ (421 ha) during the same period. Agricultural land expanded by $0.07 \%$ per annum over the same period. For protected area that are well guarded using the army, the rate of deforestation is two times the deforestation rate in other protected areas in the country. Deforestation and forest degradation was observed to be more intense around the vicinity of the three villages Mulkharkha, Chilaune gaun and Okhreni. The key drivers of forest land conversion include harvesting of firewood, timber and alcohol production. Development of alternative livelihood options to control production of alcohol, promotion of alternative energy (such as gas, kerosene or electricity) and raising awareness may help control current deforestation and land conversion inside SNNP.

\section{ACKNOWLEDGEMENTS}

ICIMOD provided financial support for the study. The authors also acknowledge the local people of the Sundarijal VDC for their valuable support during field study.

\section{REFERENCES}

Awasthi, K.D. 2004. Land Use Change Effect on Soil Degradation, Carbon and Nutrient Stock and Green House Gaseous Emissions in Mountain Watershed. Published Dissertation in Agriculture University of Norway.

Bhattari, K.R, B.B. Shrestha and H.D. Lekhak. 2008. Water Quality of Sundarijal reservoir and its feeding streams in Kathmandu. Scientific World 6:99-102.

ECOPRINT VOL 20, 2013 
CBS. 2008. Environment Statistics of Nepal. Central Bureau of Statistics, Kathmandu, Nepal.

CIESIN. 2002. A CIESIN Thematic Guide to Land Use and Land Cover Change. Center for International Earth Science Information Network, New York, USA.

DeFries., R., A. Hansen, B.L. Turner, R. Reid And J. Liu. 2007. Land use change around protected area: management to balance human needs and ecological functions. Ecological Applications 17:1031-1038.

Dhital, N. 2009. Reducing emission from deforestation and degradation (REDD) in Nepal: exploring the possibilities. Journal of Forest and Livelihood 8(1):1684-0186.

DoF. 2005. Forest Cover Change Analysis of The Terai Districs. Department of Forest, Ministry of Forestry and Soil Conservation, Kathamndu, Nepal.

FAO. 2010. Global Forest Resources Assessment. Food and Agriculture Organization, Rome, United Nations.

Ghimire, K.B. 1994. Conservation and Social Development: A Study Based on an Assessment of Wolong and Other Panda Reserve in China. Discussion Paper 56. Geneva, United Nations Research Institute of Sustainable Development.
IUCN. 2008. Investigating the Delivery of Ecosystem Economic Benefit for Upland Livelihoods and Downstream Water Users in Nepal. Policy Brief 1, 2 and 3, The cost and benefit of conserving Shivapuri National Park catchment. International Union for Conservation of Nature, Kathmandu, Nepal.

Lamichhane, B.R. 2008. Dynamics and Driving Forces of Land Use/Forest Cover Changes and Indicators of Climate Change in Mountain Sub-Watershed of Gorkha. Dissertion in Institute of Foresty, Nepal.

Panta, K.P. and G. Rasul. 2008. Can Conservation of Watershed Increases Water Supply Around Kathmandu Valley? An Empirical Analysis. Integrated Center of International Mountain Development, Kathmandu.

Phong, L.T. 2004. Analysis of Forest Cover Dynamics and their Forces in Bach Ma National Park and Buffer Zone Using Remote Sensing and GIS. Institute for Geo-information Sciences and Earth Observation. Enschedem, Netherland.

Sundarijal VDC. 2008/09. Village Development Profile: Sundarijal VDC. Sundaijal VDC, Kathmandu, Nepal

Vitousek, P.M., H.A. Mooney, J. Lubchenco and J.M. Melillo. 1997. Human domination of earth's ecosystems'. Science 277:494-499. 